\title{
Synchronization with estradiol benzoate in the presence of the corpus luteum in Wagyu cows increases the number of medium follicles but does not interfere with in vitro production of embryos
}

\section{Sincronização com benzoato de estradiol na presença do corpo lúteo em vacas de Wagyu aumenta o número de folículos médios, mas não interfere com a produção in vitro de embriões}

Maria Fernanda Zamai ${ }^{1}$; Fábio Luiz Bim Cavalieri2*; Marcia Aparecida Andreazzi²; Fábio Morottiं; Marcelo Marcondes Seneda3; José Maurício Gonçalves dos Santos ${ }^{4}$; Danieli Aparecida Bóbbo Moreski ${ }^{5}$; Antonio Hugo Bezerra Colombo ${ }^{4}$

\section{Highlights}

We evaluated OPU with CL and without association with estrogen.

Estrogen plus $\mathrm{CL}$ increased number of follicles sized 6 - $8 \mathrm{~mm}$.

It is possible to obtain good blastocyst rates independent of estrogen.

\begin{abstract}
Reproductive biotechnologies are emerging as an important element for livestock; however, some strategies must be modified to adapt to different breeding systems, such as the use of follicular synchronization protocols. This study aimed to evaluate follicular synchronization using estradiol benzoate (EB), in the presence of the corpus luteum (CL) from Wagyu oocyte donors in in vitro embryo production (IVEP). Rounds of IVEP were performed in heifers and cows $(n=19)$ that were classified into three groups: $G 1 / C L$ - animals with $\mathrm{CL}$, G2/WCL - animals without $\mathrm{CL}$, and G3/CL + EB - animals with $\mathrm{CL}$ that were subjected to follicular synchronization with $\mathrm{EB}$ at D0. The groups $\mathrm{G} 1 / \mathrm{CL}$ and $\mathrm{G} 2 / \mathrm{WCL}$ were considered the control and undertook

1 Veterinarian, MSc, Unicesumar University, UNICESUMAR, Maringá, PR, Brazil. E-mail: mfernanda.zamai@hotmail.com

2 Profs. PhD, Veterinary Medicine, Graduate Program of Clean Technology, UNICESUMAR/ ICETI, Maringa, PR, Brazil. E-mail: fbim52@hotmail.com; marcia.andreazzi@unicesumar.edu.br

3 Profs. PhD, Laboratory of Animal Reproduction, State University of Londrina, DCV/CCA, UEL, Londrina, PR, Brazil. E-mail: fabiomorotti@uel.br; marcelo.seneda@uel.br

4 Profs. PhD, Veterinary Medicine, Graduate Program of Clean Technology, UNICESUMAR/ ICETI, Maringa, PR, Brazil. E-mail: jose.santos@unicesumar.edu.br; antonio.colombo@unicesumar.edu.br

${ }^{5}$ Biology Science Graduate Program of Clean Technology, UNICESUMAR/ ICETI, Maringa, PR, Brazil. E-mail: danieli. moreski@unicesumar.edu.br

* Author for correspondence
\end{abstract}

Received: July 17, 2020 - Approved: Jan. 21, 2021 
the natural process of follicular dynamics. The results showed that the synchronization of the follicular wave with the application of $E B$ in the presence of $C L$, presented a smaller number of small $(6.05 \pm 0.55)$ and large follicles $(0.45 \pm 0.15)$, but increased $(P<0.05)$ the number of medium-sized follicles $(16.20 \pm 0.90)$. However, the results of ovum pick up showed that regardless of whether or not EB was applied, and regardless of the presence or absence of $C L$ in the Wagyu donor, there was no difference among the groups $(P>0.05)$ concerning the number of viable oocytes and the viability rate. It was concluded that follicular synchronization using EB in Wagyu oocyte donors that presented a $C L$, increased the number of medium-sized follicles. However, there was no improvement in the efficiency of ovum pick up, in vitro embryo production, and pregnancy rate.

Key words: Reproduction biotechnology. Wagyu donors. Follicular aspiration. Follicular synchronization.

\section{Resumo}

As biotecnologias reprodutivas estão emergindo como um elemento importante para a pecuária, entretanto, algumas estratégias devem ser modificadas para se adaptar a diferentes sistemas de criação, como o uso de protocolos de sincronização folicular. Este estudo teve como objetivo avaliar a sincronização folicular utilizando benzoato de estradiol (BE), na presença do corpo lúteo (CL) de doadoras de oócitos Wagyu na produção in vitro de embriões (PIVE). Sessões de PIVE foram realizadas em novilhas e vacas $(n=19)$ que foram classificadas em três grupos: G1/CL - animais com CL, G2/SCL - animais sem CL e G3/CL+BE animais com CL que foram submetidos para sincronização folicular com BE em D0. Os grupos G1/CL e G2/ SCL foram considerados o controle e realizaram o processo natural da dinâmica folicular. Os resultados mostraram que a sincronização da onda folicular com a aplicação de BE na presença de $C L$, apresentou um menor número de folículos pequenos $(6,05 \pm 0,55)$ e grandes $(0,45 \pm 0,15)$, mas aumentou $(P<0,05) \circ$ número de folículos de tamanho médio $(16,20 \pm 0,90)$. No entanto, os resultados da ovum pick up mostraram que independente da aplicação ou não de BE, e independente da presença ou ausência de CL na doadora Wagyu, não houve diferença entre os grupos $(P>0,05)$ quanto ao número de oócitos viáveis e a taxa de viabilidade. Concluiu-se que a sincronização folicular por meio de BE em doadoras de oócitos Wagyu que apresentaram CL, aumentou o número de folículos de tamanho médio. No entanto, não houve melhora na eficiência da ovum pick up, na produção in vitro de embriões e na taxa de prenhez.

Palavras-chave: Biotecnologia de reprodução. Doadoras Wagyu. Aspiração folicular. Sincronização folicular.

\section{Introduction}

The beef production chain in Brazil stands out on the world market because the country has the largest commercial bovine herd and is the world's largest exporter of beef (Associação Brasileira das Indústrias Exportadoras de Carnes [ABIEC], 2018). However, to maintain this prominent position, it is necessary to use technologies and investments in production systems (Carvalho
\& Zen, 2017). Among these technologies, breeding biotechnologies stand out as they promote genetic improvement, and maximize the productive and reproductive potential of the herd. This results in better carcass yield, and increased quantity and quality of meat products (Abrão, Castro Fernandes, \& Pessoa, 2016; Lustosa, Barboza, Barbosa, Rodrigues \& Magalhães Neto, 2018; Simplício \& Pierre, 2018). 
Among the biotechniques of reproduction, in vitro production of embryos (IVPE) stands out. This method allows the dissemination of embryos (Colombo et al., 2017) and achieves a greater number of high genetic descendants from the same female with high zootechnical potential (Almeida, Braga, Fernandes, Sotomaior, \& Pereira, 2016). In this technique, donors of oocytes from six months of age, that are either pregnant until the third month or in the postpartum period, are subjected to in-vivo follicular aspiration guided by ultrasound (Ovum pick up - OPU), without the need to use a hormonal stimulus (Mello, Ferreira, Sousa, Mello, \& Palhano, 2016).

It is known that the use of hormonal protocols for synchronization in the emergence of follicular waves improves the results of IVEP. This is because it increases the number of homogeneous follicles and allows for the recovery of oocytes with higher quality, resulting in a greater number of embryos. This is due to the fact that these protocols provide greater control of the recruitment and growth phases of ovarian follicles, thereby minimizing the chances of puncturing atretic follicles (Cavalieri et al., 2018).

The combination of progesterone (P4) with estradiol benzoate $(\mathrm{EB})$ is one of the main hormonal protocols for inducing follicular atresia by inhibiting the release of folliclestimulating hormone (FSH) and luteinizing hormone (LH) (Ramos et al., 2010). Several studies have shown that the use of this protocol increases the number of follicles, improves the rate of oocyte recovery, and increases the number of embryos (Ramos et al., 2010; Gimenes et al. 2015; Ongaratto, RodriguezVillamil, Tribulo, \& Bó, 2015; Cavalieri et al., 2018). However, it appears that there are few reports on the use of this protocol in Wagyu bovine females (Hidaka, Fukumoto, Yamamoto,
Ogata, \& Horiuchi, 2018)

The Wagyu breed, of Japanese origin, was introduced in Brazil in order to expand the breed roll and offer a product with differentiated quality. Its meat is recognized worldwide for its tenderness, juiciness, and flavor, characteristics that are the result of the carcass having high levels of marbling and high amounts of unsaturated fat (Taninaka, Bernardino, Meneghini, \& Santos, 2015). Therefore, promoting this breed brings economic advantages to Brazil.

Thus, considering the scarcity of research, the economic importance of the Wagyu breed, and the competitiveness of Brazilian livestock in the international market, this study aimed to evaluate whether follicular synchronization using estradiol benzoate in the presence of the corpus luteum can improve IVEP efficiency in donor cattle of Wagyu oocytes.

\section{Materials and Methods}

The experiment was carried out at Unicesumar Farm in 2019 and was approved by the Ethics Committee on the Use of Animals (013/2019). For this study, Wagyu heifers and cows ( $n=19$ ) aged 12 to 24 months, with an average live weight of $350 \mathrm{~kg}$, were selected to receive five rounds of OPU at 15-day intervals, totaling 64 OPU. At the beginning of each round, females were evaluated (D-1) by ultrasound and classified into three groups: G1/WCL animals without corpus luteum ( $n=24), G 2$ / $C L$ - animals with corpus luteum ( $n=20)$, and $\mathrm{G} 3 / \mathrm{CL}+\mathrm{EB}$ - animals with corpus luteum that were subjected to follicular synchronization at DO, with $1 \mathrm{mg}$ of estradiol benzoate $(E B$, Estrogin ${ }^{\circledR}$, Biofarm, Jaboticabal, Brazil); $(n=20)$ administered intramuscularly (IM; Figure 1) 


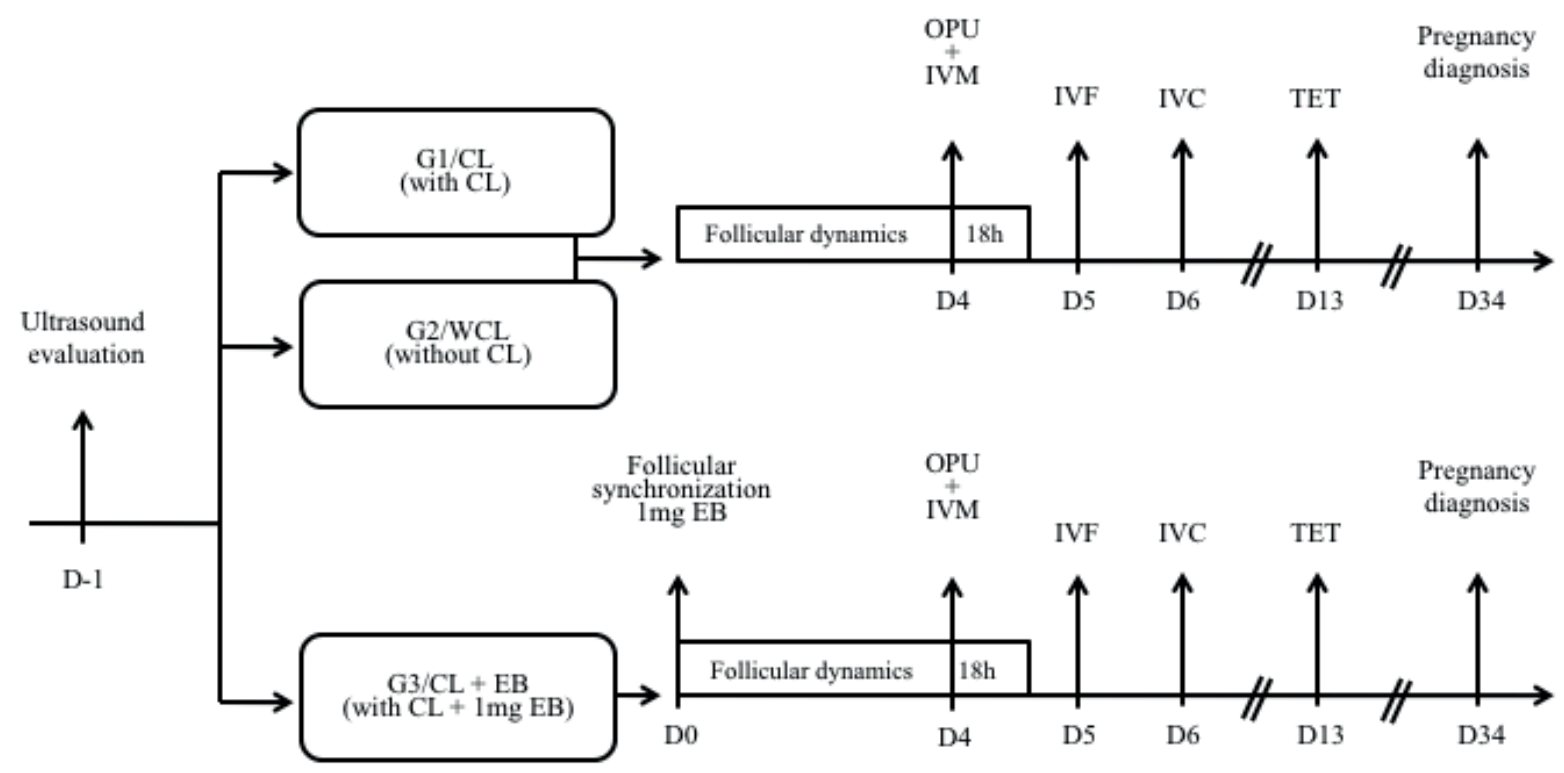

Figure 1. Experimental protocol for groups: animals without corpus luteum (G1/WCL), animals with corpus luteum (G2/CL), and animals with corpus luteum that were subjected to follicular synchronization at Day 0, with $1 \mathrm{mg}$ of estradiol benzoate (G3/CL + EB). OPU - ovum pick up, IVM in vitro maturation, IVF - in vitro fertilization, IVC - in vitro cultivation, TET - timed embryo transfer.

The OPU was performed on all females on D4 (4th day after $1.0 \mathrm{mg}$ of estradiol benzoate). At the time of the procedure, epidural anesthesia with $5 \mathrm{~mL}$ of $2 \%$ lidocaine (LIDOVET ${ }^{\circledR}$, Bravet, Rio de Janeiro, Brazil) was used. Furthermore, the ovarian follicles were identified, quantified, and classified according to their diameter: from $3 \mathrm{~mm}$ to $5 \mathrm{~mm}, 6 \mathrm{~mm}$ to $8 \mathrm{~mm}$, and equal to or greater than $9 \mathrm{~mm}$ (Ferreira, Viana, Camargo, Sá \& Pereira, 2004). Follicular aspiration was performed by an ultrasound machine (MINDRAY DP-2200Vet) equipped with a $5 \mathrm{mHz}$ microconvex transducer (UST 974-5) and a 20 gauge needle connected to a $50 \mathrm{~mL}$ Falcon tube through a suction system (Cook VBOA $18 \mathrm{~L}{ }^{\circledR}$ ) with pump (Cook V-MAR 5000). The oocytes were aspirated with a solution containing $2.0 \%$ bovine fetal serum (BFS) (Nutricell ${ }^{\circledR}$ ), $25 \mathrm{IU} / \mathrm{mL}$ sodium heparin, and 98.0\% PBS (Nutricell ${ }^{\circledR}$ ). The aspirated material was filtered, washed, and transferred to a Petri dish in order to count and classify the oocytes into the categories: viable and non-viable (De Loos, Van Vliet, Van Maurik, \& Kruip, 1989).

In vitro maturation (IVM) was performed in TCM199 with Earles salts (Gibco $\left.{ }^{\circledR}\right)$, glutamine $\left(\right.$ Sigma $\left.{ }^{\circledR}\right)$, and $\mathrm{NaHCO}_{3} \quad$ (Mallinckrodt $\left.{ }^{\circledR}\right)$; supplemented with $10 \%$ FBS (Cultilab $\left.{ }^{\circledR}\right), 22 \mu \mathrm{g} /$ $\mathrm{mL}$ pyruvate (Biochemical ${ }^{\circledR}$ ), $50 \mu \mathrm{g}$ gentamicin (Sigma ${ }^{\circledR}$ ), $0.5 \mu \mathrm{g} \mathrm{FSH} / \mathrm{mL}$ (Bioniche ${ }^{\circledR}$ ), $50 \mu \mathrm{g} \mathrm{LH} /$ $\mathrm{mL}$ (Bioniche ${ }^{\circledR}$ ), and $1 \mu \mathrm{g}$ estradiol $/ \mathrm{mL}$ (Sigma ${ }^{\circledR}$ ). This was then kept in an oven at $38.5^{\circ} \mathrm{C}$ with $5 \% \mathrm{CO}_{2}$ at maximum humidity for 22 to 24 hours. The oocytes were placed in $90 \mu \mathrm{L}$ microdroplets of maturation medium covered with mineral oil.

In vitro fertilization (IVF) was performed in $100 \mu \mathrm{L}$ of TALP medium supplemented with $10 \mu \mathrm{g} / \mathrm{mL}$ of heparin $\left(\right.$ Sigma $^{\circledR}$ ), $22 \mu \mathrm{L}$ / 
$\mathrm{mL}$ of pyruvate (Biochemical $\left.{ }^{\circledR}\right), 50 \mu \mathrm{g} / \mathrm{mL}$ of gentamicin $\left(\right.$ Sigma $\left.^{\circledR}\right)$, bovine serum albumin - BSA (Sigma $\left.{ }^{\circledR}\right), 2 \mu \mathrm{M}$ penicillin PHE solution (Sigma $\left.{ }^{\circledR}\right), 1 \mu \mathrm{M}$ hypotaurine (Sigma ${ }^{\circledR}$ ), and 0.25 $\mu \mathrm{M}$ epinephrine (Sigma ${ }^{\circledR}$ ) using $1 \times 10^{6}$ Wagyu bull sperm $/ \mathrm{mL}$. Afterwards, the oocytes were transferred to the microdroplets (20 oocytes/ drop), where they remained for 18 hours, at $38.5^{\circ} \mathrm{C}$ in an atmosphere containing $5 \% \mathrm{CO}_{2}$.

The zygotes were grown via in vitro cultivation (IVC) in SOF medium (Synthetic Oviduct Fluid) supplemented with BFS (Cultilab ${ }^{\circledR}$ ), for 18 hours in an incubator with a gaseous atmosphere $\left(5 \% \mathrm{CO}_{2}\right.$ in air) under maximum humidity. Seven days later, the embryos were evaluated, packaged, and later transferred into synchronized recipients. The pregnancy diagnosis was performed 30 days after OPU by transrectal ultrasound.

\section{Statistical analysis}

The effect of the treatment was analyzed using the generalized linear model and, in the presence of a significant effect, the means were compared using the LSMEANS test. Differences in the rate of follicle size and the rates of oocyte recovery, viable oocytes, and embryos produced, were analyzed using the Poisson distribution model. All variables were analyzed using the PROC GENMOD procedure of the statistical program Statistical Analyses System [SAS] (2000), version 8.01, and the LSMEANS means test that includes the Wald chi-square test. A significance level of $\leq 0.05$ was considered.

\section{Results and Discussion}

The results showed that the synchronization of the follicular wave with the application of EB, in the presence of the corpus luteum (CL), presented a smaller number of small and large follicles, but increased $(P<0.05)$ the number of medium-sized follicles (16.20 \pm 0.90). In addition, synchronization provided an increase in the total number of follicles $(22.70$ \pm 1.06 ) in relation to the other groups. Notably, donors in the G1/WCL group had the largest number of small follicles (Table 1).

\section{Table 1}

Number of small, medium, and large follicles, as well as the total number of follicles from ovum pick up in Wagyu donors in the absence of corpus luteum (CL; G1/WCL), with $\mathrm{CL}$ present (G2/CL), and $\mathrm{CL}$ presence associated estradiol benzoate (EB) application (G3/CL+EB)

\begin{tabular}{ccccc} 
Variables & G1/WCL & G2/CL & G3/CL+EB & P-value \\
\hline Small follicles $(M \pm E P)$ & $11.21 \pm 0.68^{\mathrm{a}}$ & $8.40 \pm 0.65^{\mathrm{b}}$ & $6.05 \pm 0.55^{\mathrm{c}}$ & 0.0001 \\
Medium follicles $(\mathrm{M} \pm \mathrm{EP})$ & $7.75 \pm 0.57^{\mathrm{b}}$ & $7.50 \pm 061^{\mathrm{b}}$ & $16.20 \pm 0.90^{\mathrm{a}}$ & 0.0001 \\
Large follicles $(\mathrm{M} \pm \mathrm{EP})$ & $1.37 \pm 0.24^{\mathrm{a}}$ & $1.55 \pm 0.28^{\mathrm{a}}$ & $0.45 \pm 0.15^{\mathrm{b}}$ & 0.0007 \\
Total follicles $(\mathrm{M} \pm \mathrm{EP})$ & $20.33 \pm 0.92^{\mathrm{a}}$ & $17.45 \pm 0.93^{\mathrm{b}}$ & $22.70 \pm 1.06^{\mathrm{a}}$ & 0.0010
\end{tabular}

${ }^{1} \mathrm{G} 1 /$ WCL1 = group of animals without the presence of $\mathrm{CL}$ who did not receive $\mathrm{EB} ;{ }^{2} \mathrm{G} 2 / \mathrm{CL}=$ group of animals with $\mathrm{CL}$ who did not receive $\mathrm{BE} ;{ }^{3} \mathrm{G} 3 / \mathrm{CL}+\mathrm{EB}=$ group of animals with the presence of $\mathrm{CL}$ and that received $\mathrm{EB}$ at $\mathrm{DO}$. $\mathrm{CL}=\mathrm{corpus}$ luteum; $W C L=$ without the presence of corpus luteum; $E B=$ estradiol benzoate. Same letters on the same line do not differ $(P>0.05) . M \pm E P=$ mean and standard error of the mean. 
In the present study, we showed that follicular synchronization with EB in the presence of CL 4 days before OPU, was effective in increasing the number of mediumsized follicles, which are associated with greater oocyte viability. Although this hormonal application has not improved the IVEP program yield, we emphasize that the strategy described here is simple and practical for use in follicular control before OPU in Wagyu. It also contributes to a better understanding of this subject in this cattle breed.

Regarding the reduction in the number of small and large follicles, and the increase in the number of medium-sized follicles, Hidaka et al. (2018) reported data similar to that of this study. They had used 15 Wagyu (Bos taurus) oocyte donor cows that received 1 mg of EB 88 hours before OPU. These authors then observed an increase in the number and proportion of medium-sized follicles $4 \mathrm{~mm}$ to 6 $\mathrm{mm}$ in diameter $(36.6 \pm 3.0$ vs. $27.8 \pm 1.8)$ at the time of the OPU. In contrast, Cavalierietal.(2018) had observed an effect of synchronization on the IVEP in 20 Bos indicus oocyte donor cows synchronized on D0 with P4 implants, 2 mg EB, and $150 \mathrm{mg} \mathrm{D}$-cloprostenol. In the experiment done by Cavalieri et al. (2018), the OPU was performed on D5. The authors suggested that the synchronization of the estrous cycle phase for the OPU procedure allows the aspiration of more homogeneous follicles in relation to size and development, whilst favoring the recovery of more competent oocytes.

In fact, the synchronization of a new follicular wave by hormonal pharmacological induction is effective for obtaining medium and homogeneous follicles, thereby enabling the recovery of more viable oocytes. This is due to the growth phase, as the oocytes do not have cumulus cell expansion (Gimenes etal., 2015). In this context, we emphasize that the findings of the present study partially agree with data from the literature. For example, the synchronization of the follicular wave emergence before OPU had increased the number of oocytes obtained and blastocysts produced in Bos taurus, but not in Bos indicus breeds (Bó, Cedeño, \& Mapletoft, 2019). Curiously, we did not find any effect of synchronization on embryo production in Bos taurus animals, whereas in Bos indicus cattle, Cavalieri et al. (2018) observed that synchronization pre-OPU improved IVEP performance.

The results of OPU efficiency in the evaluated groups (Table 2) showed that the number of viable oocytes and the viability rate, depending on the application of EB and the presence or absence of CL in Wagyu donor, did not differ among groups. However, the number of total oocytes was higher in the group of animals without $\mathrm{CL}$ and which did not receive EB. 


\section{Table 2}

Number of viable oocytes and the total number of oocytes, along with the viability rate, from ovum pick up in Wagyu donors. These donors fell in the following categories, those with: the absence of corpus luteum (CL; $\mathrm{G} 1 / \mathrm{WCL}$ ), with $\mathrm{CL}$ present (G2/CL), and $\mathrm{CL}$ presence associated estradiol benzoate (EB) application (G3/CL+EB)

\begin{tabular}{|ccccc|}
\hline Variables & $\mathrm{G} 1 / \mathrm{WCL}^{1}$ & $\mathrm{G} 2 / \mathrm{CL}^{2}$ & $\mathrm{G} 3 / \mathrm{CL}+\mathrm{EB}^{3}$ & $\mathrm{P}$-value \\
\hline Viable oocytes $(\mathrm{M} \pm \mathrm{EP})$ & $12.83 \pm 0.73$ & $10.50 \pm 0.72$ & $11.00 \pm 0.74$ & 0.0550 \\
\hline Total oocytes $(\mathrm{M} \pm \mathrm{EP})$ & $17.21 \pm 0.85^{\mathrm{a}}$ & $14.30 \pm 0.84^{\mathrm{b}}$ & $15.00 \pm 0.87^{\mathrm{ab}}$ & 0.0379 \\
\hline Viability rate $(\%)$ & 73.57 & 74.76 & 74.74 & 0.9986
\end{tabular}

${ }^{1} \mathrm{G} 1 / \mathrm{WCL} 1=$ group of animals without the presence of $\mathrm{CL}$ who did not receive $\mathrm{EB} ;{ }^{2} \mathrm{G} 2 / \mathrm{CL}=$ group of animals with $\mathrm{CL}$ who did not receive $\mathrm{BE} ;{ }^{3} \mathrm{G} 3 / \mathrm{CL}+\mathrm{EB}=$ group of animals with the presence of $\mathrm{CL}$ and that received $\mathrm{EB}$ at $\mathrm{DO}$. $\mathrm{CL}=\mathrm{corpus}$ luteum; $\mathrm{WCL}=$ without the presence of corpus luteum; $\mathrm{EB}=$ estradiol benzoate. Same letters on the same line do not differ $(P>0.05) . M \pm E P=$ mean and standard error of the mean.

In a study conducted with 27 heifers of different breeds, 9 Bos taurus (Holstein), 9 Bos indicus (Nelore) and 9 buffalos (Mediterranean), which were synchronized with $50 \mathrm{mg}$ progesterone, $2 \mathrm{mg} \mathrm{EB}$, and 150 mg D-cloprostenol, Gimenes et al. (2015) showed that OPU performed until the fifth day of pharmacological induction did not affect the number of follicles, oocyte recovery, or the rate of blastocyst production. Therefore, we emphasize that while this context is still not well understood, it seems that pre-OPU synchronization may be more linked to the population of antral follicles than the donor subspecies (Seneda, Zangirolamo, Bergamo, \& Morotti, 2020). Thus, OPU without follicular wave control possibly increases the likelihood of OPU from atretic follicles, as revealed by Cavalieri et al. (2018).

An important point to be considered is that synchronization prevents the presence of the dominant follicle at the time of the OPU procedure. This is because it induces follicular atresia by inhibiting the release of FSH, thereby initiating a new wave of growth. Although not used in this study, most synchronization protocols recommend the use of a luteolytic agent, whilst avoiding the presence of a CL at the time of OPU (Seneda et al., 2020). This strategy can improve follicle identification and puncture, as CL is considered a physical barrier, preventing the optimal performance of the procedure.

A study that performed OPU in 24 Holstein cows aged 4 to 6 years, synchronized with two applications of PGF $2 \alpha$ at intervals of 11 days, found that the best IVEP results from the oocytes recovered during the follicular growth phase in the absence of CL (Machatkova, Jokesova, Horky, \& Krepelova, 2000). Furthermore, Bacelar, Max, Padilha, Barreiros and Seneda (2010) conducted a study on 14 Nelore heifers (Bos taurus indicus) who received, on D0, $2 \mathrm{mg}$ EB, $0.5 \mathrm{mg}$ cloprostenol sodium, and $50 \mathrm{mg}$ of $\mathrm{P4}$, withe OPU performed on D6. The authors concluded that the hormonal protocol promoted the absence of $\mathrm{CL}$ at the time of OPU, providing a greater average number of follicles and oocytes. This is in addition to the improvement in the ease of locating and puncturing the follicles, as well as the reduction of vascular perfusion with less 
blood uptake. However, while investigating the importance of the timing of the follicular growth wave on IVEP using slaughterhouse ovaries from Bos indicus females ( $n=173$ ), Silva et al. (2019) observed that the presence of $C L$, associated with the absence of a dominant follicle, facilitated the recovery of oocytes with greater competence in the IVEP program.

The findings of this study on the efficiency of OPU differ from those in the literature. Bacelar et al. (2010) reported that the use of the hormonal protocol increased the average number of oocytes. Further, Cavalieri et al. (2018) stated that the use of hormonal protocols for follicular wave synchronization allows the recovery of oocytes with higher quality, because the hormonal synchronization protocol provides greater control of the recruitment and growth phases of ovarian follicles.

Data from IVEP (Table 3) showed that the number of embryos produced, and the blastocyst rate depending on whether or not EB was applied and whether or not CL was present in Wagyu donors, did not differ $(P>0.05)$; neither did the rate of pregnancy.

Table 3

Number of embryos produced, blastocyst rate, and pregnancy rate from ovum pick up in Wagyu donors in the absence of corpus luteum (CL; G1/WCL), with CL present (G2/CL), and CL presence associated estradiol benzoate (EB) application (G3/CL+EB)

\begin{tabular}{ccccc|}
\hline Variables & $\mathrm{G} 1 / \mathrm{WCL}^{1}$ & $\mathrm{G} 2 / \mathrm{CL}^{2}$ & $\mathrm{G} 3 / \mathrm{CL}+\mathrm{EB}^{3}$ & $\mathrm{P}$-value \\
\hline Embryos produced $(\mathrm{M} \pm \mathrm{EP})$ & $2.75 \pm 0.34$ & $2.40 \pm 0.35$ & $2.85 \pm 0.38$ & 0.6506 \\
\hline Blastocyst rate $(\%)$ & 19.16 & 24.50 & 26.44 & 0.8696 \\
Pregnancy rate (\%) & 32.26 & 37.78 & 40.35 & 0.6437
\end{tabular}

${ }^{1} \mathrm{G} 1 / \mathrm{WCL} 1$ = group of animals without the presence of $\mathrm{CL}$ who did not receive $\mathrm{EB} ;{ }^{2} \mathrm{G} 2 / \mathrm{CL}=$ group of animals with $\mathrm{CL}$ who did not receive $\mathrm{BE} ;{ }^{3} \mathrm{G} 3 / \mathrm{CL}+\mathrm{EB}=$ group of animals with the presence of $\mathrm{CL}$ and that received $\mathrm{EB}$ at $\mathrm{DO}$. $\mathrm{CL}=\mathrm{Corpus}$ luteum; $\mathrm{WCL}=$ without the presence of corpus luteum; $E B=$ estradiol benzoate. Same letters on the same line do not differ $(P>0.05) . M \pm E P=$ mean and standard error of the mean.

Considering the IVEP data, especially with regard to the increase in the number of antral follicles, several studies have shown that the use of hormonal protocols with EB increases the rate of oocyte recovery and the number of embryos (Ramos et al., 2010; Gimenes et al., 2015; Ongaratto et al., 2015; Cavalieri et al., 2018; Hidaka et al., 2018). However, this is a fact that was not observed in this study.
Cavalieri et al. (2018) conducted a study to evaluate the effects of the synchronized emergence of follicular waves on the efficiency of IVPE. The researchers used 20 Bos indicus cows, divided into two groups: the control (10) and the synchronized (10). The animals in the synchronized group received an intravaginal implant of P4, EB, and PGF2 $\alpha$ at D0, and OPU was performed at D5. After IVPE, embryos were transferred to already synchronized recipients. The authors reported that donors 
who received the synchronization protocol produced a greater number of embryos and had a higher rate of embryonic production, as well as a greater average number of conceptions.

In a similar study, Hidaka et al. (2018) evaluated the effectiveness of treatment with EB in the luteal phase and the IVPE of 15 Wagyu bovine females. The oocyte donors received $1 \mathrm{mg}$ of EB and, subsequently, they were examined by ultrasound examination to observe the dynamics and appearance of a new follicular wave (72 and 96 hours post). Further, OPU was performed 88 hours after induction. The results indicated that EB stimulation significantly increased the number of mediumsized aspirated follicles, the quality of cumulusoocyte complexes, and the percentage of transferable blastocysts. However, in the present study, we found only an increase in the average number of follicles, which led to the aspiration of more homogeneous follicles with regard to size.

\section{Conclusion}

Based on the results obtained, it is concluded that follicular synchronization using estradiol benzoate in Wagyu donors presenting a corpus luteum, increased the number of medium-sized follicles, which led to the aspiration of more homogeneous follicles with regard to size. However, the efficiency of OPU, IVEP, and pregnancy rate did not improve.

\section{Acknowledgments}

This study was funded by the Cesumar Institute of Science, Technology and Innovation - ICETI / Unicesumar, Maringá, Paraná, Brazil.

\section{References}

Abrão, F. O., Castro Fernandes, B. de, \& Pessoa, M. S. (2016). Produção sustentável na bovinocultura: princípios e possibilidades. Revista Brasileira de Agropecuária Sustentável, 6(4), 61-73. doi: 10.21206/ rbas.v6i4.380

Almeida, M. D. O. B., Braga, H., Fernandes, M. B., Sotomaior, C. S., \& Pereira, J. F. S. (2016). Comparação da Produção in vitro de Embriões nas Raças Red Angus e Aberdeen Angus. Revista Eletrônica Biociências, Biotecnologia e Saúde, 6(15), 235-236.

Associação Brasileira das Indústrias Exportadoras de Carnes (2018). Perfil da pecuária no Brasil. (Relatório Anual, 2017). São Paulo: ABIEC.

Bacelar, D., Max, M. C., Padilha, L. C., Barreiros, T. R. R., \& Seneda, M. M. (2010). Incremento na obtenção de oócitos em novilhas Nelore (Bos taurus indicus) tratadas com progesterona injetável e benzoato de estradiol. Semina: Ciências Agrárias, 31(1), 163-171.

Bó, G. A., Cedeño, A., \& Mapletoft, R. J. (2019). Strategies to increment in vivo and in vitro embryo production and transfer in cattle. Animal Reproduction, 16(3), 411-422. doi: 10.21451/1984-3143-AR 2019-0042

Carvalho, T. B., \& De Zen, S. (2017). A cadeia de pecuária de corte no Brasil: evolução e tendências. Revista iPecege, 3(1), 85-99. doi: 10.22167/r.ipecege.2017.1.85

Cavalieri, F. L. B., Morotti, F., Seneda, M. M., Colombo, A. H. B., Andreazzi, M. A., Emanuelli, I. P., \& Rigolon, L. P. (2018). Improvement of bovine in vitro embryo production by ovarian follicular wave 
synchronization prior to ovum pickup. Theriogenology, 117(1), 57-60. doi: 10.1016/j.theriogenology. 2017.11.026

Colombo, A. H. B., Cavalieri, F. L. B., Andreazzi, M. A., Moreski, D. A. B., Arruda Botelho, A. C. F. de, \& Santos, J. M. G. dos. (2017). Avaliação de biotécnicas da reprodução sob o foco ambiental. Archives of Veterinary Science, 22(1), 81-89. doi: 10.5380/avs.v22i1.50814

De Loos, F., Van Vliet, C., Van Maurik, P., \& Kruip, T. A. (1989). Morphology of immature bovine oocytes. Gamete research, 24(2), 197-204. doi: 10.1002/mrd.1120240207

Ferreira, A. D. M., Viana, J. H. M., Camargo, L. S. D. A., Sá, W. F. D., \& Pereira, P. A. C. (2004). População folicular ovariana durante o ciclo estral em vacas da raça Gir. Revista Brasileira de Zootecnia, 33(6), 1689-1694. doi: 10.1590/S151635982004000700007

Gimenes, L. U., Ferraz, M. L., Fantinato, P. Neto, Chiaratti, M. R., Mesquita, L.G., Sá, M .F. Fo.,... Baruselli, P. S. (2015). The interval between the emergence of pharmacologically synchronized ovarian follicular waves and ovum pickup does not significantly affect in vitro embryo production in Bos indicus, Bos taurus, and Bubalus bubalis. Theriogenology, 83(3), 385-93. doi: 10.1016/j.theriogenology.20 14.09 .030

Hidaka, T., Fukumoto, Y., Yamamoto, Y., Ogata, Y., \& Horiuchi, T. (2018). Estradiol benzoate treatment before ovum pick-up increases the number of good quality oocytes retrieved and improves the production of transferable embryos in Japanese Black cattle. Veterinary and Animal Science, 5(1), 1-6. doi: 10.1016/j.vas.2018.02.001
Lustosa, A. A., Barboza, N. A., Barbosa, Y. G. D. S., Rodrigues, P. K. O., \& Magalhães, F. D. C. R. Neto, (2018). Aspectos relevantes na produção comercial de embriões bovinos por meio da técnica biotecnológica de fertilização in vitro: Revisão. PUBVET, 12(3), 130. doi: 10.22256/pubvet.v12n3a51. 1-6

Machatkova, M., Jokesova, E., Horky, F., \& Krepelova, A. (2000). Utilization of the growth phase of the first follicular wave for bovine oocyte collection improves blastocyst production. Theriogenology, 54(4), 543-550. doi: 10.1016/S0093-691X (00)00369-1

Mello, R. R. C., Ferreira, J. E., Sousa, S. L. G. D., Mello, M. R. B. D., \& Palhano, H. B. (2016). Produção in vitro (PIV) de embriões em bovinos. Revista Brasileira de Reprodução Animal, 40(2), 6458-6458.

Ongaratto, F. L., Rodriguez-Villamil, P., Tribulo, A., \& Bó, G. A. (2015). Effect of follicle wave synchronization and gonadotropin treatments on the number and quality of cumulus-oocyte complex obtained by ultrasound-guided ovum pick-up in beef cattle. Animal Reproduction, 12(4), 876883.

Ramos, A. F., Rumpf, R., Câmara, J. U., Mollo, M. R., Pivato, I., Marques, A. P., Jr., \& Sartori, R. (2010). Effect of follicular wave synchronization on in vitro embryo production in heifers. Animal Reproduction Science, 117(3-4), 201-207. doi: 10.1016/j. anireprosci.2009.04.009

Seneda, M. M., Zangirolamo, A. F., Bergamo, L. Z., \& Morotti, F. (2020). Follicular wave synchronization prior to ovum pick-up. Theriogenology, 150(1), 180-185. doi: 10.1016/bs.agron.2016.10.002 
Silva, N. C., Sanches, T. K., Morotti, F., Zangirolamo, A. F., Orsi, M. L., \& Seneda, M. M. (2019). Influência da fase de atividade ovariana sobre a produção in vitro de embriões bovinos. Anais da Reunião Anual da Sociedade Brasileira de Tecnologia de Embriões, Ilha de Comandatuba, BA, Brasil, 33.

Simplício, A. P. G., \& Pierre, F. C. (2018). Genetic improvement: use of visual score in cutting livestock. Tekhne e Logos, 9(2), 36-47.
Statistical Analyses System (2000). SAS. Versão 8,0. Cary, North Carolina: The SAS Institute.

Taninaka, T., Bernardino, T., Meneghini, R., \& Santos, G. dos. (2015). Análise da viabilidade econômica de um rebanho de gado de corte da raça Wagyu em ciclo completo. Revista iPecege, 1(2), 44-58. doi: 10. 22167/r.ipecege.2015.2.44. 44 
